\title{
Neo-Ekstraktivisme Tambang Timah di Pulau Bangka
}

Indonesian Journal of Religion and Society, 2020, Vol. 02 (01), 12-22

(C) The Journal, 2020

DOI: $10.36256 /$ ijrs.v2i1.95

www.journal.lasigo.org/index.php/IJRS

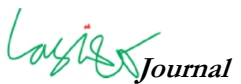

Article History

Received: Mei, $6^{h} 2020$

Revised: Mei, $22^{\text {th }} 2020$

Accepted: Mei, 26 th 2020

\section{Agung Nugraha}

Ombudsman Republik Indonesia, Perwakilan Kepulauan Bangka Belitung, Indonesia anugraha503@gmail.com

\section{Semiarto A. Purwanto}

Departemen Antropologi, FISIP Universitas Indonesia, Depok, Jawa Barat, Indonesia semiarto.aji09@ui.ac.id

\begin{abstract}
Tin mining on Bangka Island was monopolized by large companies since the colonial period until twenty years ago. Furthermore, illegal tin miners or unconventional mines (tambang inkonvensional or TI) are the main actors in tin exploitation. We conducted research on the network of tin mining actors to explain the social relations, capital, and business of tin miners. Through the case study method, we observed and interviewed our informants during the March-October 2018 period. Within the neo-extractivism framework, we examined that TI players were connected to the mining business supported by global investment through a network of sub-collectors, collectors, and the smelting industry. This network serves to legalize the tin obtained by TI while ensuring the supply of industrial raw materials to support exports. We conclude that there has been a shift from production to distribution sectors. When emphasis on production processes, various institutional decays occur which involve state actors in it. Next, as attention is paid to the distribution chain, a shadow network that hides behind official companies emerges.
\end{abstract}

Keywords: Bangka, Bendera, Shadow Network, Neo-Extractivism, Tin Mining

\begin{abstract}
ABSTRAK
Penambangan timah di Pulau Bangka, sejak masa kolonial hingga dua puluh tahun yang lalu, dimonopoli oleh perusahaan besar. Selanjutnya, penambang timah liar atau tambang inkonvensional (TI) menjadi aktor utama dalam eksploitasi timah. Kami melakukan studi kasus pada jaringan pelaku tambang di Pulau Bangka untuk menjelaskan hubungan sosial, modal, dan bisnis para penambang timah. Pengamatan dan wawancara dilakukan selama periode Maret-Oktober 2018. Dengan kerangka neo-ekstraktivisme, kami melihat TI terhubung ke bisnis pertambangan yang didukung oleh investasi global melalui jaringan sub-kolektor, kolektor, dan industri smelter. Jaringan ini berfungsi untuk melegalkan timah yang diperoleh TI sambil memastikan pasokan bahan baku industri untuk ekspor. Kami menyimpulkan bahwa telah terjadi pergeseran perhatian pada proses penambangan timah, dari sektor produksi ke distribusi. Ketika penekanan ditempatkan pada aspek produksi, berbagai pembusukan institusi terjadi dengan melibatkan aktor-aktor negara. Ketika memperhatikan rantai distribusi, yang muncul adalah jaringan bayangan yang bersembunyi di belakang satu atau dua perusahaan resmi.
\end{abstract}

Kata Kunci: Bangka, Bendera, Jaringan Bayangan, Neo-Ektraktivisme, Tambang Timah

Corresponding Author

Name : Semiarto A. Purwanto

Email : semiarto.aji09@ui.ac.id 


\section{Pendahuluan}

Paradigma pembangunan negara berkembang atas tata kelola sumber daya alam pada saat ini berorientasi pada penambahan nilai suatu komoditi ekspor untuk mendorong pertumbuhan industrialisasi dan ekonomi. Ketergantungan terhadap sektor ekstraktif amat tinggi, sehingga perubahan politik nasional dan distribusi modal transnasional akan mempengaruhi pembentukan formasi-formasi sosial baru pada sektor ekstraktif di tingkat lokal. Artikel ini akan membahas dinamika para pelaku pertambangan inkonvensional (uconventional mining) timah di Pulau Bangka akibat regulasi nasional yang didorong oleh perubahan konstelasi politik internasional dan investasi global.

Indonesia memiliki pengalaman luar biasa bagaimana dampak perubahan politik menyebabkan eksploitasi sumber daya alam berubah kerangka kerjanya. Hidayat (2008) menunjukkan bagaimana perubahan pengelolaan hutan amat dipengaruhi oleh perubahan politik nasional. Di masa Orde Lama, pengelolaan sumberdaya alam dilakukan secara amat terbatas, selain akibat kurangnya modal dan teknologi, obsesi pengelolaan secara mandiri juga mengakibatkan tidak optimalnya pemanfaatan sumberdaya alam. Di awal Orde Baru, Jendral Suharto bekerja dengan arahan tim ekonomi dan teknologi yang kuat mendapat dukungan negara-negara Barat yang berorientasi kapitalis. Kekecewaan akibat sentra pengelolaan sumberdaya yang terpusat pada perusahaan-perusahaan keluarga atau dekat dengan kekuasaan, menyebabkan tuntutan reformasi bergema kencang. Memasuki milenium baru, masyarakat lokal mulai mendapat akses untuk memanfaatkan sumber daya alam secara terbuka, melalui otonomi daerah dan desentralisasi kekuasaan (Baiquni $\&$ Rijanta, 2007). Reformasi dan desentralisasi adalah dua kunci utama perubahan sistem kelembagaan dan distribusi kuasa pada tingkat daerah yang dihasilkan oleh kesepakatan dengan pemilik modal dalam merumuskan kebijakan (Pigome, 2011: Maladi, 2013; Rachman, 2018). Menariknya dinamika pada industri ekstraktif tidak hanya memberikan akses kepada masyarakat untuk mengeksploitasi tetapi juga untuk melakukan renegosiasi penerbitan regulasi pendirian industri pengolahan sumber daya alam. Kebijakan untuk mendirikan smelter sendiri bagi pelaku usaha pertambangan menjadi kontroversi dalam banyak kasus (Adam, 2014; Contesa \& Rahmatunnisa, 2018).

Pada tahun 2005, industri smelter mulai menjamur di Pulau Bangka (Zulkarnain, et. al, 2005) yang merupakan salah satu daerah penghasil terbesar timah di Indonesia. Industri smelter adalah industri yang mengolah, memurnikan, dan memperdagangan produk timah dan produk lainnya dari timah ke dalam dan luar negeri. Kehadiran industri smelter sebagai salah satu solusi dari pemerintah pusat dan daerah untuk mengatasi masalah penyelundupan, tambang ilegal, dan kerusakan lingkungan (Adam, 2014). Akan tetapi, industri smelter ternyata mendorong dominasi operasional tambang inkonvensional yang berdampak pada kerusakan lingkungan (Contesa \& Rahmatunnisa, 2018).

Veltmeyer (2014: 80-83) menggunakan istilah reprimarization yang terjadi di Amerika Latin untuk mengambarkan suatu keberlanjutan eksploitasi karena melimpahnya ketersedian sumber daya alam sebagai komoditi utama penggerak pertumbuhan ekonomi. Dalam proses ekploitasinya, telah terjadi pergeseran dengan melibatkan investasi asing yang berorientasi resource-seeking dan akuisisi lahan untuk produksi komoditi ekstraktif melalui sokongan kapital transnasional. Dalam konteks tulisan ini, investasi asing merujuk pada suatu bentuk baru dari pemberian modal (capital flow) eksploitasi sumber daya timah pada sektor swasta. Sebelumnya, ekploitasi timah di Pulau Bangka didominasi oleh perusahaan negara, yaitu PT. Timah dan PT. Koba Tin. Proses eksploitasi sumber daya tidak hanya berurusan dengan akuisisi lahan di lokasi tambang yang menjadi konsesi perusahaan negara, tetapi juga invasi lahan milik pribadi, negara, dan milik komunal (seperti di wilayah perairan darat dan laut).

Lebih jauh kami melihat bahwa aktivitas penambangan ilegal, apalagi dalam skala yang besar, tidaklah mungkin terjadi begitu saja. Kajian Erman (2008) menunjukkan bagaimana timah digali dan dipasarkan ke luar negeri secara ilegal. Dari awal, produksi timah di pulau ini dikemas secara informal melalui lembaga penambangan yang disebut sebagai tambang inkonvensional, disingkat TI. Para pelaku mengeruk timah di daratan atau menyedot dari laut, dan memasarkannya ke Perusahaan Negara (PN) Timah sebagai bagian dari suplai perusahaan tersebut. Persoalan harga dan kapasitas produksi membuat beberapa pengusaha TI memilih menjual ke luar, secara ilegal. Seperti kami sampaikan di atas, tidak mungkin aparat sebagai bagian dari negara tidak mengetahui aktivitas ini. Legalisasi usaha TI sendiri merupakan bagian dari praktek untuk memberikan lisensi pada aktivitas informal dan kolutif (Yunianto, 2009). Urusan perizinan sebagai legalisasi dari kegiatan 
penambangan menunjukkan fenomena turutnya negara dalam proses kolusif mengekstraksi sumberdaya alam bersama para aktor lain (Mc Carthy, 2011; Erman, 2017).

Peran negara dalam memfasiltasi aktivitas abu-abu itu dinyatakan dalam keterlibatan birokrasi pada kasus-kasus kegiatan ilegal (Berenschot \& van Klinken, 2018:100). Di Indonesia, bahkan keterlibatan para aktor negara dalam aktivitas ilegal sudah amat transparan dan diketahui masyarakat umum (Aspinall \& van Klinken, 2011: 2). Di dalam negara, pada birokrasi, para aktor itu bekerja sebagai perwakilan resmi negara, ini adalah fenomena negara-dalam-negara (states-within-states) yang mudah dilihat oleh orang di luar birokrasi sekalipun. Dalam prakteknya, seolah-olah ada negara bayangan (shadow states) yang menguasai praksis penyelenggaraan negara secara informal (Hidayat, 2007). Riset mengenai hal ini sudah cukup banyak dilakukan di Indonesia (Erman, 2008; Nevins \& Peluso, 2009; McCarthy, 2011).

Melalui tulisan ini kami mengajukan dua argumen yang saling kait. Pertama, TI tidak lagi bisa dipandang sebagai sekedar small scale mining dan artisanal mining semata, tetapi melalui jaringan yang panjang dan rumit, telah berubah menjadi bagian dari mata rantai pertambangan global. Kedua, telah terjadi perubahan bentuk dari negara bayangan pada perdagangan komoditi timah menjadi jaringan bayangan yang terpusat pada penambangan timah, yang digerakkan oleh redistribusi kapital oleh elit industri dengan membuat jaringan baru (jaringan bayangan). Kami merujuk pada teori-teori neo-ekstraktivisme di Amerika Latin yang meletakkan ekspor komoditi pada proses ekstraksi, yang didukung aliran modal transnasional dalam eksploitasi dan perdagangan sumber daya alam (Gudynas, 2010; Burchardt \& Dietz, 2014; Svampa, 2019). Kajian kami akan mengakumulasi pengetahuan tentang aspek neo-ekstraktivisme dengan memfokuskan perhatian pada jaringan bendera yaitu perusahaan formal dan legal yang membawahi praktek TI sebagai jaringan bayangan dalam penambangan timah di Pulau Bangka. Lebih khusus studi ini mengindentifikasi perkembangan dan aktor-aktor yang terlibat dari jaringan perusahaan bendera, yang secara singkat akan kami sebut bendera, dengan menguraikan pengalaman dari para sub-kolektor dan kolektor besar.

\section{Metode Penelitian}

Untuk mendapatkan data mengenai TI, jaringan kolektor dan sub kolektor, dan pelaku industri smelter, kami melakukan penelitian yang bersifat kualitatif, yang amat terbuka terhadap dinamika temuan di lapangan. Berbagai kasus (Marvasti, 2004:7) kami identifikasi, terutama untuk mendapatkan gambaran bagaimana beroperasinya masingmasing pelaku industri timah di Pulau Bangka. Wawancara mendalam dilakukan dengan menerapkan sejumlah kriteria khusus (Fetterman, 2010:40), dalam hal ini kami mengidentifikasi terlebih dahulu pelaku TI, sub kolektor, dan kolektor. Tiga informan utama dan tiga informan pendukung kami wawancara secara mendalam, meliputi kolektor timah, aktivis LSM, birokrat, dan pengusaha smelter dan timah.

Walapun pembicaraan dalam artikel ini adalah mengenai usaha penambangan timah di Pulau Bangka secara umum, namun kami mengambil kasus di wilayah Kabupaten Bangka, yaitu di Kecamatan Pemali dan Merawang. Penjajakan untuk penelitian dilakukan selama sebulan pada Januari 2018, dilanjutkan dengan pengambilan data secara mendalam selama 8 bulan pada Maret-Oktober 2018. Dalam penelitian, kami melakukan pengamatan lapangan secara cermat ke lokasi tambang dari informan. Pengamatan pada interaksi antar informan juga kami lakukan untuk mengkonfirmasi proses networking para informan yang saling terhubung antara satu sama lain. Mengingat sebagian besar informasi bersifat personal dan confidential, kami menyamarkan nama pelaku dan nama badan usahanya.

Sejumlah data sekunder kami kumpulkan untuk mendukung analisis data, terutama terkait dengan berbagai kajian yang telah dilakukan mengenai penambangan timah di Pulau Bangka dan berbagai persoalannya. Data tersebut juga mencakup kajian mengenai pendekatan konseptual untuk memberi kerangka penjelasan dan kajian dari media massa sebagai pemicu untuk wawancara dan traingulasi data

\section{Rantai Komoditi dan Modal Tambang Timah Inkonvensional}

Kami mengidentifikasi ada tiga pelaku dalam mata rantai produksi pada konteks jaringan bayangan penambangan sumber daya timah, yaitu para pekerja tambang inkonvensional, kolektor timah, dan industri smelter. Saat ini, relasi tiga aktor tersebut saling mempengaruhi dan tidak dapat dipisahkan. Untuk menjelaskan mata rantai tersebut, kami melihat pertambangan sebagai rangkaian proses eksploitasi sumber daya tambang yang 
dimulai dengan proses penggalian, pengolahan, pemurnian, pengangkutan, dan berakhir dengan pengemasan dan penjualan (Zulkarnain, et. al 2005). Masing-masing aktor memegang peran tertentu dalam rangkaian proses eksploitasi sumber daya alam berdasarkan kemampuan yang telah terstruktur. Biasanya, tambang inkonvensional memiliki peran pada proses penggalian. Kolektor timah berada pada proses pengolahan biji timah yang disiapkan untuk didistribusikan kepada industri smelter atau yang dikenal dengan istilah lobi atau melobi. Sedangkan industri smelter, melakukan proses pemurnian biji timah menjadi timah batangan atau produk lainnya dari timah, sekaligus mengemas produk komoditi timah untuk kepentingan perdagangan baik dalam dan luar negeri.

Mata rantai pertama adalah tambang inkonvensional atau TI. Dalam konteks global, TI masuk dalam kategori artisanal and small scale mining atau tambang informal. Saat ini, praktek TI telah mengarah pada tindakan memformalkan perizinan eksploitasi dengan menggunakan lisensi yang diterbitkan oleh industri smelter dalam bentuk Surat Izin Tampung yang dipegang oleh Kolektor Timah. Walaupun terlihat sederhana, tetapi surat itu efektif memberikan keamanan usaha. TI termasuk dalam kategori artisanal and small scale mining karena memiliki karakteristik menggunakan teknologi produksi sederhana, produktivitas rendah, minimnya aspek keselamatan kerja dan memiliki dampak lingkungan (Zulkarnain, et.al 2007). Sekalipun demikian, TI juga mendapatkan sokongan modal dari investor asing sebagai pengelola bayangan (shadow manager) melalui tangan-tangan pengusaha lokal yang melakukan penyelundupan (Erman, 2007; 2008 \& 2010). Maraknya penyelundupan mendorong ekonomi ilegal dari eksploitasi sumber daya timah oleh TI.

Penelitian kami menunjukkan bahwa kuasa modal yang diberikan oleh pengusaha lokal tersebut, biasanya adalah pengusaha elit industri smelter, telah membentuk struktur mata rantai nilai dan komoditi yang meliputi dua pihak lainnya, yaitu kolektor timah dan industri smelter. Penggerak alur relasi antar mereka terpusat pada pengusaha elit melalui industri smelter yang dipegangnya. Kepentingan kapital transnasional dengan suntikan modal untuk memperoleh komoditi timah dalam konteks perdagangan pasar dunia melalui jaringan bayangan yang terpusat pada industri smelter telah menciptakan kompetisi dengan perusahaan negara. Kami sepakat dengan Lahiri-Dutt (2018), yang menjelaskan bahwa berlangsungnya tambang informal menunjukkan pengaruh dari proses kapitalisasi dan industrialisasi terutama pada rantai nilai dan suplai komoditi global.

Dalam proses formalisasi TI, ada kecenderungan intervensi pemerintah atas segala bentuk legalisasi. Formalisasi dipandang sebagai serangkaian proses bersama tiga elemen dasar, yaitu hak terhadap lahan, hak terhadap mineral, dan hak untuk menambang (Barney, 2018:339). Namun, pada TI terdapat suatu perbedaan mendasar terkait formalisasi, yaitu adanya kuasa yang menandai industri smelter dengan menerbitkan lisensi perizinan kepada kolektor timah oleh elit industri untuk berkolaborasi dengan TI. Penting sekali untuk dicatat bahwa formalisasi tidak hanya tertuju pada TI, tetapi pada kolektor timah yaitu pada hak untuk membeli dan menjual kembali. Meskipun tidak semua TI berkolaborasi dengan kolektor timah, namun kolaborasi antara kedua belah pihak terlihat begitu jelas.

Kehadiran industri smelter seperti memperlihatkan pemihakan negara pada pemilik modal untuk lebih terlibat dalam usaha penambangan. Di sisi lain, negara dalam hal ini Pemerintah Provinsi Bangka Belitung terkesan membiarkan TI beroperasi secara ilegal dengan tidak diterbitkannya Wilayah Pertambangan Rakyat (WPR) dan Izin Pertambangan Rakyat (IPR) di Kabupaten Bangka. Menariknya, di Kabupaten Bangka Barat, lisensi IPR telah diterbitkan pada tahun 2017, namun WPR belum ditetapkan. Dengan demikian, timbulnya tambang informal, dalam hal ini TI menunjukkan lemahnya pengelolaan negara sekaligus mengindikasikan kepentingan negara atas penamaman modal (Verbrugge, 2017; Veltmeyer \& Petras, 2014).

Bagian lain dari jaringan bayangan kepentingan kapital transnasional pada industri smelter adalah para kolektor timah. Kolektor ini adalah orang yang membeli timah dari para TI dan mengumpulkannya sebelum dijual kepada perusahaan (Zulkarnain, 2005:85). Kolektor Timah terbagi menjadi dua kategori, yaitu sub-kolektor dan kolektor besar (lihat Zulkarnian, 2005: 85-86). Beberapa kajian sempat menyinggung tentang kolektor timah (Zulkarnain et. al., 2005 dan 2007; Erman, 2010, Ibrahim, 2016) telah ditulis tetapi kurang memperhatikan kepentingan dari kapital transnasional yang melekat pada kolektor timah yang dilihat dari jaringan bayangan. Mekanisme produksi para kolektor terdeskripsikan cukup jelas, relasi antara industri smelter dengan kolektor timah yang terpusat pada peran 
bendera kolektor kurang mendapat perhatian. Bagian inilah yang nanti akan kami jelaskan lebih jauh.

Secara umum kolektor timah dapat dibedakan menjadi sub-kolektor dan kolektor besar. Sub-kolektor adalah orang yang membeli biji timah dari pendulang dan TI, yang kemudian diolah dan dijual kepada kolektor besar dalam bentuk biji timah basah. Sub-kolektor tidak berhubungan bisnis dan modal secara langsung dengan industri smelter, melainkan hanya kepada kolektor besar. Modal yang digunakan oleh sub-kolektor berasal dari mereka sendiri, atau bisa berasal dari kolektor besar. Seorang sub-kolektor terikat pada satu kolektor besar karena akses terhadap industri smelter yang hanya dimiliki kolektor besar. Selain itu, kolektor besar siap untuk mem-back up sub-kolektor dan mengurusi segala bentuk surat izin yang dikeluarkan oleh industri smelter, seperti Surat Tampung dan Surat Jalan. Hal ini bertujuan untuk menunjukkan bahwa sub-kolektor berpatron dengan salah satu jaringan bayangan dari industri smelter tertentu. Meskipun hal ini bisa mengaburkan praktik illegal mining, tetapi tidak begitu signifikan. Pada dasarnya para aparat sudah mengetahui jaringan bayangan dari smelter milik siapa yang berbisnis menambang, membeli, dan mendistribusikan biji timah dari TI kepada kolektor timah, serta dari kolektor timah kepada industri smelter yang berada di wilayahnya. Tidak hanya melalui modal, relasi sub-kolektor dengan kolektor besar juga terjalin dengan perusahaan bendera tambang. Perusahaan ini adalah pihak yang memegang surat izin yang dikeluarkan oleh industri smelter agar TI dapat bekerja secara legal.

Sub-kolektor melakukan pemisahan biji timah dengan cara lobi. Istilah ini dipakai karena adanya proses menyepakati standar kandungan stannum (Sn.) dari mineral timah. Semakin tinggi kandungan stannum, maka semakin mahal harga yang dibeli oleh kolektor besar. Biji timah yang dihasilkan dari pengolahan oleh sub-kolektor disebut sebagai timah basah. Para sub-kolektor membeli biji timah secara langsung ke TI di lokasi tambang atau menunggu mereka mengantarkannya ke rumah atau tempat usaha.

Kolektor besar memiliki hubungan secara resmi dengan industri smelter melalui perjanjian kontrak pengiriman biji timah. Dalam aspek legalitas, kolektor besar mengantongi Surat Izin Tampung yang dikeluarkan oleh industri smelter. Mereka mendapat modal dari bendera secara selektif. Modal para pengusaha bendera kolektor besar ditengarai berasal dari investor luar negeri melalui pemilik industri smelter. Para pemilik industri smelter memiliki hubungan bisnis dengan investor luar negeri dalam kepentingan perdagangan komoditi timah di pasar dunia. Anatomi bisnisnya semakin rumit karena para pengusaha bendera kolektor bisa juga berasal dari pemilik industri smelter bayangan (tak berijin), pemilik resmi industri smelter, pemegang modal dari investor luar negeri, anggota organisasi tambang, bahkan keluarga dari para pihak yang berkepentingan terhadap industri smelter.

Kolektor besar melakukan proses pengolahan dengan cara mereduksi konsentrat biji timah dengan suhu yang tinggi (Nur, 2016), dengan tungku besar (Zulkarnain, et.al, 2005:86), atau dengan melobi. Pada proses ini kolektor besar harus mendapatkan kadar biji timah atau stannum di atas 70 untuk menghasilkan biji timah kering. Kegiatan ini dilakukan di rumah mereka yang terhubung langsung dengan tempat pengolahan biji timah yang berada di belakang atau di samping rumah kolektor besar. Umumnya, mereka menampung biji timah dari para pendulang, TI, dan jaringan sub-kolektor mereka.

Pelaku terakhir adalah adalah industri smelter yang mengolah dan memurnikan biji timah menjadi produk timah sesuai ketentuan dari pemerintah agar nilai tambah suatu komoditi meningkat. Zulkarnain (2005:78), menyebutkan pada awalnya ada dua tipe industri smelter yang muncul, yaitu milik daerah dan swasta. Pada awalnya industri smelter terpisah dari industri, berdiri sebagai bisnis yang tidak harus terkait dengan sektor tambang. Namun, setelah diterbitkan UU No. 4 Tahun 2009 Tentang Pertambangan Mineral dan Batubara, maka setiap industri smelter harus memiliki Wilayah Izin Usaha Pertambangan (WIUP) dan Izin Usaha Pertambangan (IUP) yang dikeluarkan oleh Pemerintah Daerah. Meskipun demikian, industri smelter tidak dapat melepaskan kepentingannya terhadap TI karena produksi dari wilayah IUP tidak optimal suplainya ke industri.

Buruknya tata kelola pertambangan dan perdagangan biji timah mengakibatkan berbagai tindak kolusif yang menimbulkan fenomena negara bayangan (Erman, 2008). Saat pertambangan biji timah amat marak pasca desentralisasi, kehadiran industri smelter ditujukan pada upaya meningkatkan pendapatan asli daerah (PAD). Yunianto (2009) menyebutkan berbagai proses deregulasi kebijakan yang mendorong pendirian industri 
smelter di Pulau Bangka, yaitu Deregulasi pada Permenperindag No. 443/2002 dan Permenperindag No. 7/M-DAG/PER/4/2005. Kami melihat bahwa kehadiran industri smelter justru tidak membuat persaingan industri pengolahan dan pemurnian biji timah menjadi kompetitif. Fasilitasi perundang-undangan tersebut malah memunculkan bisnis timah yang tidak sehat yang dilakukan oleh industri smelter melalui jaringan bayangan. Pada jaringan yang gelap dan tidak kentara ini (dark network dan shadow network) berbagai macam aturan dan kepentingan disatukan menjadi satu tindakan ekstraktif yang disepakati bersama (Pressey et. al., 2014). Melalui jaringan gelap dan remang-remang ini, industri smelter terlibat dalam perdagangan transnasional yang memperdagangkan komoditinya kepada pihak yang telah ditunjuk oleh investor global.

Negara telah menetapkan bahwa dalam proses perdagangan komoditi timah baik ke dalam dan luar negeri harus melewati tiga mekanisme, yaitu pre trade, trade, dan post-trade (Pujiati, 2016). Pre-trade adalah proses pendaftaran dan pembayaran iuran, serta verifikasi asal dan kualitas biji timah. Trade adalah melakukan perdagangan melalui sistem online. Terakhir, post-trade adalah pembayaran royalti. Kami, terutama, menaruh perhatian pada tahapan pre-trade saat verifikasi asal biji timah yang dilakukan oleh surveyor. Data kami menunjukkan bahwa suplai biji timah diperoleh industri smelter melalui jaringan bayangan yang melegalkan praktek informal dan ilegal. Untuk itu, bagian berikut akan menguraikan peengalaman para aktor dalam berbisnis timah, yang disadari atau tidak telah melibatkan mereka ke dalam suatu jaringan tertentu.

\section{Pengalaman Para Pelaku Bisnis Timah di Pulau Bangka 4.1. Bisnis Dengan Modal Orang Lain}

Membuka usaha selalu membutuhkan modal yang tidak hanya sebatas keterampilan dan pengalaman, tapi tentu harus dilengkapi dengan modal finansial. Demikian pula dengan bisnis TI di Pulau Bangka. Kami menemukan bahwa sebagian dari pelaku harus memiliki modal yang cukup kalau ingin tidak sekedar menjadi buruh. Namun, jaringan sosial juga amat berperan dalam hal ini. Informan kami, Abok memulai pekerjaan sebagai sub-kolektor sejak mulai tahun 2010 sampai 2014, setalah sebelumnya menjadi buruh pada mitra pertambangan PT. Timah. Abok memiliki bos seorang kolektor besar bernama Sarno yang tinggal di Desa Matras, Kecamatan Sungailiat. Sarno merupakan kolektor besar dari industri smelter CV. Girimayah di Desa Air Ruay, Sungailiat-Bangka. Saat penelitian berlangsung, perusahaan tersebut beralih kepemilikannya ke Bos Kamkam, seorang pengusaha dan politisi lokal Bangka. Selain menjalankan usaha bersama keluarganya, Bos Kamkam menjadi mitra pertambangan dari perusahaan negara. Karena rekam jejak itulah maka ia bisa mendirikan industri smelter resmi. Oleh karena itu, industri smelter tersebut berfungsi sebagai perusahaan bendera bagi para pelaku TI. Para kolektor timah dari CV. Girimayah menggunakan identitas Bendera Kamkam. Sarno memulai bisnisnya saat berkenalan dengan salah satu keluarga Kamkam yang berbisnis timah juga.

Dalam menjalankan usahanya, Abok lebih banyak menggunakan modal kolektor besar daripada modal milik sendiri. Ia memiliki keuntungan banyak ketika bermitra dengan Bos Sarno yang merupakan jaringan bayangan dari bendera Kamkam. Suatu kali, ia pernah ditangkap oleh aparat kepolisian ketika membawa biji timah, namun Bos Sarno mengurus segala urusan dengan aparat kepolisian untuk melepaskan Abok. Tentu ada biaya yang dikeluarkan oleh Bos Sarno untuk membebaskannya. Namun, upaya Sarno membebaskan Abok sebenarnya sudah dipermudah oleh Bos Kamkam yang memberikan uang setoran setiap bulan pada setiap pos keamanan di Kecamatan dan Kabupaten. Setoran itu untuk memperlancar usaha pembelian dan pengangkutan biji timah yang dilakukan oleh jaringan kolektor timah di Wilayah Kabupaten Bangka.

Abok membeli biji timah dari pendulang, para penambang, dan sesama sub-kolektor lain. Wilayah kerja Abok adalah daerah Kecamatan Pemali, Riau Silip, dan Belinyu. Di Kecamatan Pemali, Abok mengantongi Surat TSK (Tambang Skala Kecil) dari PT. Tin dan Surat Tampung dari industri smelter. Surat TSK itu memungkinkan sub-kolektor membeli biji timah dari wilayah tambang milik PT. Tin, sedangkan Surat Tampung adalah identitas bendera Kamkam. Di Kecamatan Riau Silip dan Belinyu dia menggunakan surat TSK dari temannya sesama bendera Kamkam.

Walaupun tidak memiliki TI sendiri, Abok memiliki mitra tambang. Melalui mitra tambang inilah ia mengamankan monopoli penjualan timah kepadanya. Dia sengaja memancing para pemilik tambang meminjam modal darinya untuk biaya operasional. Sebagai balasan, pemilik tambang hanya boleh menjual kepadanya. Harga beli ditetapkan oleh Abok kepada mitra 
tambang lebih rendah, yaitu 70\% dari harga pasaran umum. Sub-kolektor lain di Desa Sempan yang tidak memiliki jaringan kolektor besar, memilih menjual pada Abok yang menjamin keamanan sub-kolektor tersebut jika berhadapan dengan aparat kepolisian

\subsection{Bisnis Sebagai Sub Kolektor, Pemilik Tambang, dan Pengusaha Bendera}

Kasus kami yang kedua menunjukkan betapa strategisnya posisi tertentu dalam mata rantai TI. Sutanto merupakan aktor yang paling kompleks yang kami jumpai, ia adalah pemilik tambang, menjadi sub-kolektor, sekaligus memiliki izin resmi dari industri smelter sehingga bisa menjadi perusahaan bendera tambang. Wilayah kerjanya berada di Kecamatan Merawang. Sutanto sudah memiliki TI sejak awal kebijakan tambang inkonvensional diberlakukan sejak tahun 2001 dan menjadi sub-kolektor sekitar tahun 2014. Selain memiliki TI, dia juga memiliki usaha tambang pasir untuk bangunan dan menjadi pengurus organisasi tambang daerah. Sutanto mengantongi surat yang menerangkan bahwa lokasi tambang miliknya merupakan bagian dari industri smelter PT. Babel Tenaga Muda di Kawasan Industri Ketapang Pangkalpinang, yang kepemilikannya dikaitkan dengan keluarga pejabat daerah di Bangka Belitung. Surat tersebut mencantumkan nama seorang anggota marinir sebagai penanggungjawab lokasi tambang.

Sutanto memiliki satu TI besar dan dua TI kecil. Karena memegang surat yang dikeluarkan oleh PT. Babel Tenaga Muda, dia lalu menjadi pelindung para pelaku TI di sekitar wilayah tambang miliknya yang tidak memiliki lisensi. Setiap pemilik tambang yang berafiliasi dengannya diwajibkan untuk menjual hasil biji timah kepada Sutanto. Sutanto pernah memiliki sekitar sepuluh mitra TI. Tidak sekedar perlindungan, Sutanto juga menawarkan jasa sewa alat berat kepada pemilik TI, memberi modal usaha, dan memasok bahan bakar solar kepada penambang.

Setiap dua minggu sekali, Sutanto mengirim hasil timah yang dikumpulkannya kepada kolektor besar. Salah satu jaringannya adalah seorang saudaranya yang menjadi kolektor besar dan tinggal di belakang rumah Sutanto. Tugas Sutanto tetap mengumpulkan biji timah dari TI yang berada di kawasan Kecamatan Merawang. Meskipun demikian, dalam hal relasi dengan aparat keamanan Sutanto lebih kuat karena memiliki koneksi dengan aparat kepolisian di tingkat Kabupaten. Jaringan ini tidak terlepas dari kegiatannya berorganisasi di lembaga kepemudaan dan organisasi tambang tingkat Kabupaten Bangka. Menurut Sutanto jaringan kolektor timah dari suatu bendera, telah terdaftar di pos-pos keamanan kecamatan maupun kabupaten sehingga aman. Oleh karena itu, apabila ada kasus penangkapan terutama jaringan kolektor timah biasanya disebabkan oleh persaingan bisnis sesama kolektor timah. Persaingan di tingkat kolektor biasanya diselesaikan di tingkat mereka, tidak dibawa ke bendera smelter yang merupakan elit industri smelter. Di tingkat elit ini, aparat kepolisian pun tidak berani sembarangan menangkap kolektor timah, karena konon dapat menyebabkan anggota tersebut dimutasi.

\subsection{Bisnis Para Kolektor Besar}

Salahudin merupakan kolektor besar dan ternama di Kecamatan Merawang. Dia memulai menjadi kolektor timah sejak tahun 2008 setelah sebelumnya bekerja sebagai petani dan penambang. Salahudin tidak terafiliasi dengan satu industri smelter tertentu karena perusahaan bendera kolektornya memiliki relasi dengan sekitar lima industri smelter. Satu bendera kolektor memang bisa memiliki lebih dari satu industri smelter. Oleh karena itu, mereka dapat melacak kolektor timah yang menjual biji timah kepada industri smelter lainnya. Salahudin memperoleh modal dari kolektor besar lainnya, ia juga mengantongi Surat Izin Tampung yang dikeluarkan oleh industri smelter di Kawasan Industri Ketapang Pangkalpinang sebagai bendera. Dalam surat tersebut menerangkan lokasi IUP perusahaan industri smelter tersebut berada di wilayah Kecamatan Belinyu, namun mengingat industri smelter mengembangkan jaringan bayangan maka biji timah di wilayah Kecamatan Pemali dan Kecamatan Merawang pun dapat mereka peroleh.

Salahudin memiliki ruangan khusus di belakang rumahnya untuk menempatkan tungku besar pengolah biji timah. Ada tiga orang pegawai yang masing-masing bertugas mencuci biji timah dan mengolahnya menjadi konsentrat timah kering. Dari setiap penjualan biji timah ke industri smelter, maka bendera kolektor mendapatkan fee dari kolektor besar yang dipotong dari jumlah total uang hasil penjualan berdasarkan kadar Sn dan jumlah total pengiriman. Di sisi lain, ketika kolektor besar berurusan dengan aparat kepolisian maka utusan bendera smelter atau bendera kolektor yang akan mengurusnya. 
Ada tujuh mitra tambang dalam jaringan Salahudin di Kecamatan Pemali dan beberapa penambang dari Kecamatan Merawang yang menjual timah kepadanya. Ia bertanggungjawab atas keamanan usaha mitra tambangnya melalui koordinasi dengan bendera tambang. Melalui koordinasi ini, Salahudin tahu kapan TI dapat beroperasi, kapan ada razia, dan bagaimana mengurus segala urusan administrasi dengan industri smelter yang ditunjuk.

Salah satu mitra bendera tambang Salahudin memiliki produksi biji timah yang sangat besar, yang mampu menghasilkan biji timah lebih dari satu ton dalam waktu kurang lebih tiga bulan. Kondisi ini memberikan keuntungan pada Salahudin, bendera kolektornya, dan industri smelter PT. Bukit Mangkol karena mereka memperoleh rente yang cukup besar dari produksi dari mitra tambangnya. Namun, salah satu industri smelter yang lebih kuat tertarik dan mengambilalih tambang tersebut. Perampasan lokasi tambang dilakukan dengan cara melakukan razia tambang ilegal dengan menggunakan kuasa aparat tertinggi di Provinsi. Bahkan, bisnis kolektor timah dari Salahudin juga menjadi sasaran untuk dirazia. Salahudin berkoordinasi dengan bos bendera kolektornya untuk mengatasi masalah. Ia menawarkan bagi hasil pengiriman biji timah dari tambang besar itu dengan sang pengusaha yang lebih kuat itu. Ini adalah salah satu bentuk kompetisi, konflik dan kompromi antar elit industri yang diselesaikan dengan difasilitasi negara.

Setiap industri smelter harus mencukupi kuota ekspor yang telah ditetapkan oleh Kementerian Perdagangan dalam Surat Permohonan Ekspor (SPE). Namun, menurut para aktivis anti-tambang, ada ketimpangan antara kuota ekspor dengan tingkat serapan industri smelter yang ada. Konsumsi industri smelter tidak sampai mencapai kuota berdasarkan SPE. Oleh karena itu, eksistensi TI di berbagai wilayah Kabupaten Bangka masih terus berlangsung tanpa adanya batasan legal dan ilegal. Di sinilah kolektor timah berperan sebagai bendera tambang untuk mengembangkan jaringan bayangan untuk mendapatkan distribusi biji timah dari TI sekaligus melegalkannya. Dari pengalaman Salahudin diundang ke suatu pertemuan dengan kolektor besar lainnya, ia mengingat ada instruksi dari seorang aparat yang berpangkat tinggi kepada anak buahnya dihadapan para kolektor timah, "Tolong yang hitam pekat itu dikasih bumbu supaya jadi abu-abu". Suatu isyarat yang ia tafsirkan sebagai cara untuk melegalkan produksi TI.

Bantahan atas isu legalisasi ini muncul dari Pemerintah Daerah Provinsi. Meskipun keberadaan para kolektor timah mengantongi Surat Tampung, secara tegas Pemerintah Provinsi Bangka Belitung pernah menyatakan melalui Kepala Dinas Pertambangan dan Energi, "Saya tegaskan izin kolektor itu tidak ada dari sejak dulu sampai sekarang. Cuma PT. Timah yang memiliki IUP dan yang lainnya tidak ada, apalagi kolektor timah. Yang ada izin itu adalah izin menambang, izin angkut, dan izin jual. Mana ada izin nampung seperti kolektor timah. Kalau itu ada, ya jelas itu kegiatan ilegal dan harus ditindak secara tegas jangan sampai dibiarkan. Kalau kami Dinas tidak satu pun pernah mengantongi izin, wong tidak ada dasarnya memberi izin" (Muktar, Forum Keadilan 2017).

\section{Diskusi}

Kasus-kasus di atas menunjukkan bagaimana upaya untuk melegalkan praktek tambang ilegal yang dilakukan TI secara amat sistematis. Cukup dengan mendirikan satu perusahaan yang dilengkapi semua syarat perijinannya, yang berfungsi sebagai pemberi legalitas atas usaha yang dilakukan para pekerja, karyawan, dan jaringan buruh di dalamnya. Inilah yang disebut sebagai bendera. Dari pengalaman Abok, bendera dapat berada di tingkat smelter, berwujud persekutuan, atau gabungan industri smelter yang menumpang nama dari salah satu industri smelter untuk dapat mengeskpor produk timah.

Tidak hanya di tingkat industri smelter yang mengolah bahan mentah menjadi siap jual, di tingkat pengumpul dalam hal jual-beli biji timah di tingkal TI, perusahaan bendera juga muncul di tingkat kolektor. Pengalaman Salahudin menunjukkan bagaimana bendera kolektor yang langsung terhubung dengan jaringan industri smelter. Dapat dikatakan bahwa industri smelter yang ada hanya dimiliki orang segelintir orang saja, tetapi mereka memperbanyak industri smelter supaya dapat mengembangkan mata rantai dari jaringan bayangan untuk mendapatkan biji timah. Mata rantai ini berkembang terus di tingkat kolektor besar dan sub-kolektor. Untuk mengamankannya, diperlukan suatu perusahaan resmi sebagai bendera kolektor.

Perdagangan komoditi timah berada pada level transnasional (Rahman et al., 2011), hal ini ditunjukkan oleh aliran kapital transnasional pada sektor penambangan biji timah. Berbagai peraturan perundangan, jaringan sosial, dan jaringan bisnis telah membuat para pelaku memfokuskan diri pada proses distribusi, bukan pada produksi. Kami melihat bahwa hal ini 
telah memunculkan peranan jaringan bayangan yang mengeser upaya ilegal seperti penyelundupan yang menjadi bagian dari negara bayangan. Para pelaku tidak lagi menggunakan cara penyelundupan tetapi menggunakan cara perdagangan resmi, tetapi penuh kerumitan dan kecurangan, untuk mendapatkan bahan baku produksi untuk industri smelter dari TI. Tentu ini tidak terlepas dari kapital transnasional yang telah memperkuat elit industri agar tetap mampu menyuplai timah ke pasar dunia. Secara sederhana, bendera smelter adalah pemegang kuasa perdagangan komoditi produk timah ke pasar dunia yang bekerja dengan menggabungkan produk timah dari industri smelter lainnya yang tak berijin. Ke bawah, industri smelter ini adalah strategi elit industri untuk menghimpun biji timah dari TI melalui jaringan kolektor timah yang mereka bentuk dan modali.

Walapun terjadi pergeseran dari negara bayangan ke jaringan bayangan, tetapi kami melihat para pengelola bisnis timah di Pulau Bangka adalah aktor yang kurang lebih sama. Kami melihat para investor asing yang mengelola pendistribusian kapital transnasional ke industri penambangan biji timah telah menjadi pengelola bayangan. Mereka tidak pernah muncul dalam kegiatan sehari-hari, tetapi aliran kapitalnya menghidupi bisnis TI. Mereka membangkitkan pertumbuhan ekonomi melalui sektor pertambangan timah dan menjadikannya sebagai salah satu penyumbang pajak dan pendapatan utama bagi pemerintah dan masyarakat.

Kami mencatat paling tidak ada tiga kepentingan elit industri terhadap keberlanjutan TI dalam kerangka neo-ekstraktivisme; (1) mempertahankan ekspor komoditi timah pada aktor broker internasional, yaitu para pemodal transnasional atau pengelola bayangan walaupun ada perubahan kebijakan di tingkat regional, (2) industri smelter menjadikan Wilayah Izin Usaha Pertambangan dan Izin Usaha Pertambangan sebagai strategi legal untuk mentransformasi hasil TI ilegal melalu jaringan bayangan yang menjadikannya sebagai sebuah kegiatan formal dan legal, dan (3) munculnya perusahaan-perusahaan bendera yang dipersiapkan sebagai flag-carrier dari komoditas yang menjadi jaringan bayangan pada penambangan sumber daya timah.

Proses menjadikan timah sebagai bagian dari reprimarization dapat dilihat terutama dari dua kebijakan, yaitu perjanjian perdagangan bebas dan desentralisasi. Pasar bebas memberikan akses pada investor untuk masuk menanamkan modal, dan pada saat bersamaan, pada periode pasca reformasi, pembentukan Provinsi Bangka Belitung amat strategis bagi investasi. Pada titik ini pertumbuhan ekonomi Pulau Bangka sangat bergantung pada ekonomi ilegal sektor timah (Erman, 2008). Kebijakan di tingkat lokal, baik Provinsi maupun Kabupaten, semakin memberikan TI kesempatan melakukan eksploitasi. Proses ekstraksi sumberdaya alam terus berlangsung, tapi kini bukan terutama ditujukan untuk mencukupi kebutuhan domestik. Dengan mengambil model di negara-negara Amerika Selatan, yang mengekstraksi sumberdaya alam dengan orientasi eksport yang amat dominan, dan penanaman modal asing yang membanjir, para ahli menyebutnya sebagai gejala neoekstraktivisme (Burchardt \& Dietz, 2014; Svampa, 2019).

Salah satu pokok perhatian penting dari neo-ekstraktivisme adalah penetrasi kapital transnasional yang mampu membentuk jaringan bayangan pada sektor pertambangan (Gudynas, 2010). Pada artikel ini kami telah memperlihatkan mata rantai nilai dan komoditi yang terpusat pada produksi industri smelter yang digerakkan oleh elit industri beserta jaringan bendera yang dibentuk olehnya. Menariknya, industri tambang yang kita bicarakan bukan lagi eksploitasi tambang oleh PN Timah yang merupakan warisan tambang timah kolonial berskala besar. Saat ini, tulang punggung dari eksploitasi itu justru pada para pelaku TI yang berskala kecil tapi banyak, agresif, dan berhubungan satu sama lain. Fenomena ini mirip dengan kajian Verbrugge (2017) tentang joint institutions of extraction yang menghubungkan kepentingan politisi lokal dengan penambang berskala kecil di Filipina selatan. Berbeda dengan Verbrugge yang menekankan pentingnya posisi penambang berskala kecil, kami mengidentifkasi para kolektor timah sebagai mata rantai dalam jaringan yang juga amat penting. Mereka menjadi pusat penghubung kepentingan industri smelter dalam menyalurkan modal dan mendapatkan timah untuk kepentingan produksinya. Para kolektor yang menampung hasil tambang para TI inilah salah satu contoh konkret dari jaringan bayangan yang melegalkan output para TI melalui bendera mereka.

\section{Kesimpulan}

Kami telah mendeskripsikan jaringan perdagangan timah di Pulau Bangka dengan menunjukkan relasi para pelaku mulai dari TI, sub kolektor, kolektor, dan industri smelter. Bekerjanya relasi dan jaringan tersebut menunjukkan perubahan bentuk perdagangan 
timah yang sebulumnya terpusat tindakan penyelundupan menjadi upaya memformalkan dan melegalkan bisnis TI dan penjualan biji timah yang terpusat pada kolektor timah. Perubahan terlihat pada koordinasi jaringan bayangan penambangan timah di Pulau Bangka yang disebut bendera. Penetrasi modal transnasional telah mendorong kapitalisasi dan industrialisasi yang disertai dengan lemahnya negara dengan membiarkan penambangan timah berada pada jalur ilegal pada sektor penggalian, pengolahan, pemurnian, dan perdagangan.

Temuan lapangan kami juga menunjukkan identifikasi para aktor yang terlibat di dalam jaringan bendera tersebut. Pelaku utama bukan lagi para penambang dalam bentuk TI tetapi juga meliputi kolektor, sub kolektor, dan industri smelter. Tidak dapat dipungkiri bahwa kebijakan nasional di bidang tambang, yang mengharuskan mereka memiliki industri smelter, telah menimbulkan keguncangan. Di sisi lain, kewajiban tersebut telah mendorong investor transnasional untuk masuk menanamkan modalnya. Bukan terutama untuk membangun smelter dalam jumlah yang mencukupi, tetapi dengan membuat bendera sehingga cukup satu badan usaha legal dan formal saja untuk menaungi beberapa kegiatan. Para investor berfungsi sebagai pengelola bayangan, yang mengatur relasi dan operasi dari setiap bagian bendera dari sebuah jaringan bayangan.

\section{Ucapan Terima Kasish}

Kami berterimakasih kepada Prof. Erwiza Erman dan Dr. Ery Seda atas saran dan perspektif yang diberikan. Ucapan serupa juga kami sampaikan kepada para informan yang telah bersedia menjelaskan segala pertanyaan kami.

\section{Pendanaan}

Biaya penelitian dan penulisan artikel ini berasal dari dana pribadi penulis.

\section{Conflicts of Interest}

Data kami ambil dari hasil penelitian untuk kegiatan akademik; tidak ada konflik kepentingan dalam penulisan makalah ini

\section{Daftar Pustaka}

Adam, L. (2014). Kebijakan Mineral dan Batubara di Indonesia. Jakarta: Pusat Kajian DPR RI, Ekonomi dan Kebijakan Publik.

Aspinall, E., \& Van Klinken, G. (2011). The State and Illegality in Indonesia. Aspinall, E., \& G. Van Klinken (eds.) The State and Illegality in Indonesia. Leiden: KITLV Press.

Baiquni, M., \& Rijanta, R. (2007). Konflik Pengelolaan Lingkungan dan Sumberdaya dalam Era Otonomi dan Transisi Masyarakat. Bumi Lestari Journal of Environment, 7(1).

Berenschot, W., \& Van Klinken, G. (2018). Informality and Citizenship: The everyday state in Indonesia. Citizenship Studies, 22(2), pp. 95-11.

Barney, K. (2018). Reassembling informal mining gold for development or sustainability? Oppurtunities and Limits To Formalisation in India, Indonesia, and Laos. Dalam K. Lahiri-Dutt (Ed.). Beetwen The Plough and The Pick: Informal, Artisanal, Small-Scale Mining in The Contemporary World. Australia: ANU Press.

Burchardt, H.J., \& Dietz, K. (2014). (Neo-) extractivism-a new challenge for development theory from Latin America. Third World Quarterly, 35(3), 468-486.

Contesa, M., \& Rahmatunnisa, M. (2018). Smelter: Inkonsistensi Kebijakan, Kendala dan Dampak di Indonesia. Responsive, 1(1), 6-11.

Erman, E. (2007). Deregulasi Tata Niaga Timah dan Pembuatan Negara Bayangan Lokal: Studi Kasus Bangka. Dalam H.S. Nordholt dan G.van Klinken (Eds.). Politik lokal di Indonesia. Jakarta: Yayasan Obor Indonesia-KITLV.

Erman, E. (2008). Rethinking legal and illegal economy: A case study of tin mining in Bangka Island. Southeast Asia: History and Culture, 2008(37), 91-111.

Erman, E. (2010). Aktor, Akses, dan Politik Lingkungan di Pertambangan Timah Bangka. Jakarta: LIPI.

Erman, E. (2017). Aktor, akses dan politik lingkungan di pertambangan timah Bangka. Masyarakat Indonesia, 36(2), 71-101.

Fetterman, D. M. 2010 Ethnography: Step-by-step(Vol. 17). SAGE Publications Incorporated. 
Gudynas, E. (2010). The new extractivism of the 21st century: Ten urgent theses about extractivism in relation to current South American progressivism. Americas Program Report, 21, 1-14.

Hidayat, H. (2008). Politik lingkungan: pengelolaan hutan masa Orde Baru dan reformasi. Yayasan Obor Indonesia.

Hidayat, S. (2007) Shadow state.? Bisnis dan politik di Provinsi Banten. Dalam H.S. Nordholt dan G.van Klinken (Eds.). Politik lokal di Indonesia. Jakarta: Yayasan Obor Indonesia-KITLV.

Ibrahim (2016). Bangka tin, and the collapse of the state power. GSTF Journal of Law and Social Sciences (JLSS), 5(1), 1-7.

Lahiri-Dutt, K. (2018). Beetwen The Plough and The Pick: Informal, Artisanal, Small-Scale Mining in The Contemporary World. Australia: ANU Press.

Maladi, H. (2013). Kajian Hukum Kritis Alih Fungsi Lahan Hutan Berorientasi Kapitalis. Jurnal Dinamika Hukum, 13(1), 109-123.

Marvasti, A.M. (2004). Qualitative Research in Sociology. Sage Publications.

McCarthy, J.F. (2011). The limits of illegality: State, governance, and resource control in Indonesia. Aspinall, E. \& G. Van Klinken (eds.) The State and Ilegality in Indonesia. Leiden: KITLV Press.

Muktar, R. (2017). Jack Salah Satu Kolektor Timah Yang Masih Aman. Diakses melalui https: / / forumkeadilan.com/2017/12/jack-salah-satu-kolektor-timah-yang-masihaman/, pada tanggal 16 Februari 2019 pada pukul 18.48 WIB.

Nevins, J., \& Peluso, N.L. (2009). Taking Southeast Asia to Market: Commodities, nature, and people in the neoliberal age. Selangor, Malaysia: Strategic Information and Research Development Centre (SIRD).

Nur, H.Y. (2016). Produksi Timah di Indonesia: Potensi dan Tantangan. Dalam Z. Salim dan E. Munadi (Eds.). Info Komoditi Timah. Jakarta: Badan Pengkajian dan Pengembangan Perdagangan.

Pigome, M. (2011). Politik Hukum Pertambangan Indonesia dan Pengaruhnya Pada Pengelolaan Lingkungan Hidup di Era Otonomi Daerah. Masalah-Masalah Hukum, 40(2), 213-219.

Pujiati, R. (2016). Perdagangan Timah di Dalam Negeri. Dalam Z. Salim dan E. Munadi (Eds.). Info Komoditi Timah. Jakarta: Badan Pengkajian dan Pengembangan Perdagangan.

Rachman, N. F. (2018). Meninjau Kembali Teorisasi Mengenal Desentralisasi, Community Driven Delevopment, dan Kapitalisasi Agraria. BHUMI: Jurnal Agraria dan Pertanahan, 4(1), 1-23.

Rahman, B., Haryadi, D., Zukhri, N., Khodijah, N.S., Ibrahim, Manik, J.D.N., Sarpin, Irvani, \& Wulansari, D. (2011). Menyoal Pertimahan di Babel (Beberapa Cerita dan Gagasan). Yogyakarta. Khomsa.

Svampa, M. (2019). Neo-extractivism in Latin America: socio-environmental conflicts, the territorial turn, and new political narratives. Cambridge University Press.

Veltmeyer, H. (2014). Bolivia: Beetwen Voluntarist Developmentalism and Pragmatic Extractivism. Dalam Ed. Veltmeyer, Henry, and James Petras. New Extractivism: A PostNeoliberal Development Model or Imperialism of the Twenty-First Century. London: Zed Books Ltd.

Veltmeyer, H. \& Petras, J. (2014). New Extractivism: A Post-Neoliberal Development Model or Imperialism of the Twenty-First Century. London: Zed Books Ltd.

Verbrugge, B. (2017). Small-Scale Gold Mining and the State in the Philippines. Ed. Bettina Engels and Kristina Dietz. Contested Extractivism, Society, and the State: Strunggler over Mining and Land. London: Palgrave Macmillan.

Yunianto, B. (2009). Kajian Problema Pertambangan Timah Di Provinsi Kepulauan Bangka Belitung Sebagai Masukan Kebijakan Pertimahan Nasional. Jakarta. Jurnal Teknologi Mineral dan Batubara Vol. 5, No. 3, Juli 2009: 97-113.

Zulkarnain, I., Erman, E., Pudjiastuti, T.N., Mulyaningsih, Y. (2005). Konflik di kawasan pertambangan timah Bangka Belitung: persoalan dan alternatif solusi. Jakarta: LIPI Press.

Zulkarnain, I., Pudjiastuti, T.N., Sumanardi, E.T., Sari, B.S. (2007). Dinamika dan Peran Pertambangan Rakyat di Indonesia. Jakarta: LIPI Press 